\title{
Actinomadura alba sp. nov., isolated from soil in Yunnan, China
}

\author{
Yong-Xia Wang, ${ }^{1}+$ Xiao-Yang Zhi, ${ }^{1} \uparrow$ Hua-Hong Chen, ${ }^{1}$ Yu-Oin Zhang, ${ }^{1,2}$ \\ Shu-Kun Tang, ${ }^{1}$ Cheng-Lin Jiang, ${ }^{1}$ Li-Hua $\mathrm{Xu}^{1}$ and Wen-Jun Li ${ }^{1}$ \\ ${ }^{1}$ Yunnan Institute of Microbiology, Yunnan University, Kunming, Yunnan 650091, People's Republic \\ of China \\ ${ }^{2}$ Institute of Medicinal Biotechnology, Chinese Academy of Medical Sciences and Peking Union \\ Medical College, Beijing 100050, People's Republic of China
}

Correspondence

Wen-Jun Li

wjli@ynu.edu.cn

Li-Hua Xu

lihxu@ynu.edu.cn

\begin{abstract}
A novel actinomycete, strain YIM $45681^{\top}$, which was isolated from soil in a suburb of Kunming, Yunnan Province, China, was subjected to phenotypic and genotypic characterization. The micro-organism, which produces short spore chains arranged in spirals on the aerial mycelium, was shown to have meso-diaminopimelic acid in the cell wall. The sugars present in whole-cell hydrolysates were ribose, xylose, galactose, madurose and glucose. The predominant menaquinones were MK- $9\left(\mathrm{H}_{4}\right)$, MK- $9\left(\mathrm{H}_{6}\right)$ and MK- $9\left(\mathrm{H}_{2}\right)$. The phospholipids included diphosphatidylglycerol, phosphatidylglycerol, phosphatidylinositol and phosphatidylinositol mannoside. The major fatty acids were iso- $\mathrm{C}_{16: 1} \mathrm{H}, \mathrm{C}_{17: 1} \omega 8 \mathrm{c}, 10$-methyl $\mathrm{C}_{17: 0}$ and $\mathrm{C}_{16: 0}$. A comparative analysis of $16 \mathrm{~S}$ rRNA gene sequences indicated that the organism formed a distinct clade within the evolutionary radiation of the family Thermomonosporaceae, and that it was closely associated with members of the genus Actinomadura. A broad range of phenotypic and genetic data supported the suggestion that this organism represents a novel species of the genus Actinomadura, for which the name Actinomadura alba sp. nov. is proposed, with YIM $45681^{\top}\left(=\mathrm{DSM} 45045^{\top}=\right.$ CCTCC AA206005 $\left.{ }^{\top}\right)$ as the type strain.
\end{abstract}

The genus Actinomadura was established by Lechevalier \& Lechevalier (1970b) and its description has been emended by Zhang et al. $(1998,2001)$ and Miyadoh \& Miyara (2001). Currently, the genus comprises 35 recognized species and two subspecies with validly published names. The genus Actinomadura accommodates aerobic, Grampositive, non-acid-fast, non-motile actinomycetes that produce well-developed, non-fragmenting vegetative mycelia and aerial hyphae that differentiate into surface-ornamented spore chains. These chains are of various lengths and can be straight, hooked or spiral in form, with irregular, smooth, spiny or warty spores. Members of the genus Actinomadura are characterized chemotaxonomically by the presence of type III/B cell walls (i.e. containing meso-diaminopimelic acid and madurose) with peptidoglycan structures of the acetyl type, major proportions of hexahydrogenated menaquinones with nine isoprene units, complex fatty acid profiles, including hexadecanoic, 14-methylpentadecanoic and 10-methyloctadecanoic acids as predominant components, and diphosphatidylglycerol and phosphatidylinositol as major phospholipids (Kroppenstedt et al., 1990).

†These authors contributed equally to this work.

The GenBank/EMBL/DDBJ accession number for the 16S rRNA gene sequence of strain YIM $45681^{\top}$ is D0985164.
Strain YIM $45681^{\mathrm{T}}$ was isolated by using the following procedure. Soil samples were collected from the rhizosphere of Catharanthus roseus, at the surface and down to a depth of about $10 \mathrm{~cm}$. Soil samples were air-dried for about 7 days. One gram of the soil sample was first suspended in $9 \mathrm{ml}$ MOPS $(10 \mathrm{mM})$ containing $1 \%$ keratin and incubated for $2 \mathrm{~h}$ at $45{ }^{\circ} \mathrm{C}$ with vigorous shaking, in order to kill fast-growing bacteria and promote actinomycete spore germination. This culture was centrifuged and the supernatant was serially diluted to $10^{-3}$ and spread on a humic acid/vitamin/gellan gum (HVG; Suzuki et al., 1999) medium and incubated at $28{ }^{\circ} \mathrm{C}$ for 30 days.

Strain YIM $45681^{\mathrm{T}}$ was grown on ISP 2, ISP 3, ISP 4, ISP 5 (Shirling \& Gottlieb, 1966) and Czapek agar plates (Pridham \& Lyons, 1980) at $28{ }^{\circ} \mathrm{C}$. Colour determination was performed with colour chips from the Inter-Society Color Council-National Bureau of Standards Color Name Charts (Standard Samples, no. 2106; Kelly, 1964). Spore chains were observed using the cover-slip technique of Kawato \& Shinobu (1959). Morphological characteristics were examined by light microscopy with a model BH-2 microscope (Olympus) and scanning electron microscopy (XL30, ESEM-TMP; Philips). Morphological features were observed on ISP 4 medium at $28{ }^{\circ} \mathrm{C}$. Growth was tested over a range of temperatures $\left(4-45^{\circ} \mathrm{C}\right)$ and $\mathrm{pH}$ 


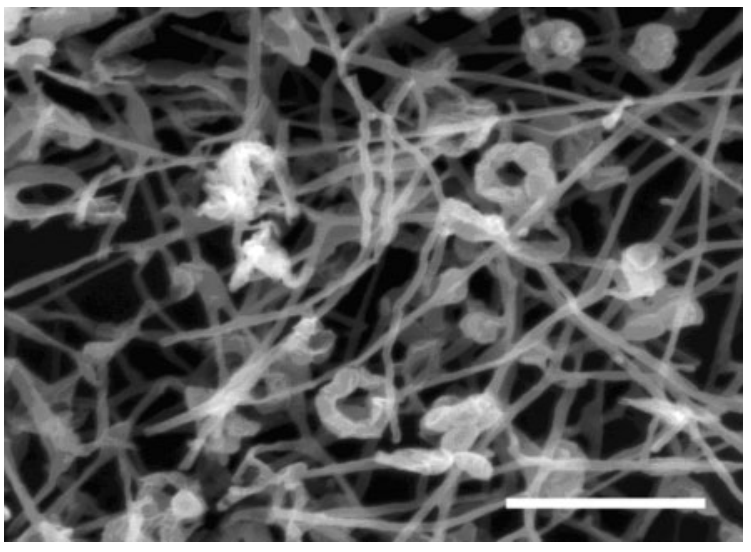

Fig. 1. Scanning electron micrograph of strain YIM $45681^{\top}$ grown on ISP 4 for 21 days at $28{ }^{\circ} \mathrm{C}$. Bar, $5 \mu \mathrm{m}$.

(pH 6.0-12.0) on ISP 2 medium. The phenotypic properties of the isolate are also consistent with its classification in the genus Actinomadura. Strain YIM $45681^{\mathrm{T}}$ grew well on ISP 2, ISP 3 and ISP 4 media, but grew only moderately well on ISP 5 and Czapek agar plates. Vegetative hyphae were well developed on all of the media tested. The whitish aerial mycelium, which was produced only on ISP 3 , ISP 4 and Czapek agar media, formed short, spiral chains of irregular-surfaced spores (Fig. 1). No diffusion pigments were produced on any of the media tested. The optimal temperature and $\mathrm{pH}$ for growth were $28^{\circ} \mathrm{C}$ and $\mathrm{pH}$ 7.0-8.0.

Physiological and biochemical characteristics of strain YIM $45681^{\mathrm{T}}$ are given in Table 1 and the species description. ISP
9 (Shirling \& Gottlieb, 1966) was used as the basic medium for testing carbohydrate utilization; each filter-sterilized compound was tested at a final concentration of $1 \%(\mathrm{w} / \mathrm{v})$. Urease activity was determined by assessing a colour change in Bacto urea broth (Difco). The production of $\mathrm{H}_{2} \mathrm{~S}$ was tested on peptone iron agar (Difco). Nitrate reduction, gelatin liquefaction and the degradation of elastin and starch were investigated by using previously described methods (MacFaddin, 1980). The decomposition of adenine, hypoxanthine, casein, DL-tyrosine and xanthine was examined by using the methods of Gordon et al. (1974).

The procedures used to identify the cell-wall amino acids and sugars in whole-cell hydrolysates were as described by Staneck \& Roberts (1974). Menaquinones were extracted by using the method of Collins et al. (1977) and were analysed by HPLC, as described by Tamaoka et al. (1983). Polar lipids were extracted as described by Minnikin et al. (1979) and identified by two-dimensional TLC and spraying with specific reagents (Collins \& Jones, 1980). Biomass for a quantitative fatty acid analysis of strain YIM $45681^{\mathrm{T}}$ was prepared by scraping growth from TSB agar plates that had been incubated for 7 days at $28{ }^{\circ} \mathrm{C}$. Fatty acids were extracted, methylated and analysed using the MIDI (Microbial Identification) system. The wall diamino acid in the peptidoglycan layer of strain YIM $45681^{\mathrm{T}}$ was meso-diaminopimelic acid and the whole-cell sugars were ribose, madurose, xylose, galactose and glucose (cell-wall chemotype III, according to Lechevalier \& Lechevalier, 1970a). The predominant menaquinones were MK$9\left(\mathrm{H}_{4}\right), \mathrm{MK}-9\left(\mathrm{H}_{6}\right)$ and $\mathrm{MK}-9\left(\mathrm{H}_{2}\right)$ (ratio of peak areas, $64.6: 18.2: 11.5)$. The phospholipids included diphosphatidylglycerol, phosphatidylinositol, phosphatidylglycerol

Table 1. Physiological and biochemical characteristics that distinguish strain YIM $45681^{\top}$ from the type strains of closely related Actinomadura species

Strains: 1, YIM $45681^{\mathrm{T}} ; 2$, A. spadix JCM $3146^{\mathrm{T}} ; 3$, A. echinospora DSM $43163^{\mathrm{T}}$. Data were taken from the present study and from Holt et al. (1994). +, Positive; w, weakly positive; -, negative; ND, no data available.

\begin{tabular}{|lccc|}
\hline Characteristic & $\mathbf{1}$ & $\mathbf{2}$ & $\mathbf{3}$ \\
\hline Spore-chain arrangement & Spirals & Hooks & $\begin{array}{c}\text { Longitudinally paired } \\
\text { spores }\end{array}$ \\
Spore-surface ornamentation & Irregular & Smooth & Spiny \\
Colour of growth on ISP 4 & & & \\
Aerial mycelium & White & Greyish yellow & Yellow-pink \\
Substrate mycelium & Greyish yellow & Dust & Greyish yellow \\
Diffusible pigment & None & Dark & Tan \\
Utilization of: & - & - & w \\
Glycerol & - & - & w \\
myo-Inositol & - & + & ND \\
D-Raffinose & - & + & + \\
L-Rhamnose & + & - & - \\
Liquefaction of gelatin & + & + & + \\
Hydrolysis of starch & - & + & - \\
Coagulation of milk & + & + & \\
Nitrate reduction & & & \\
\hline
\end{tabular}




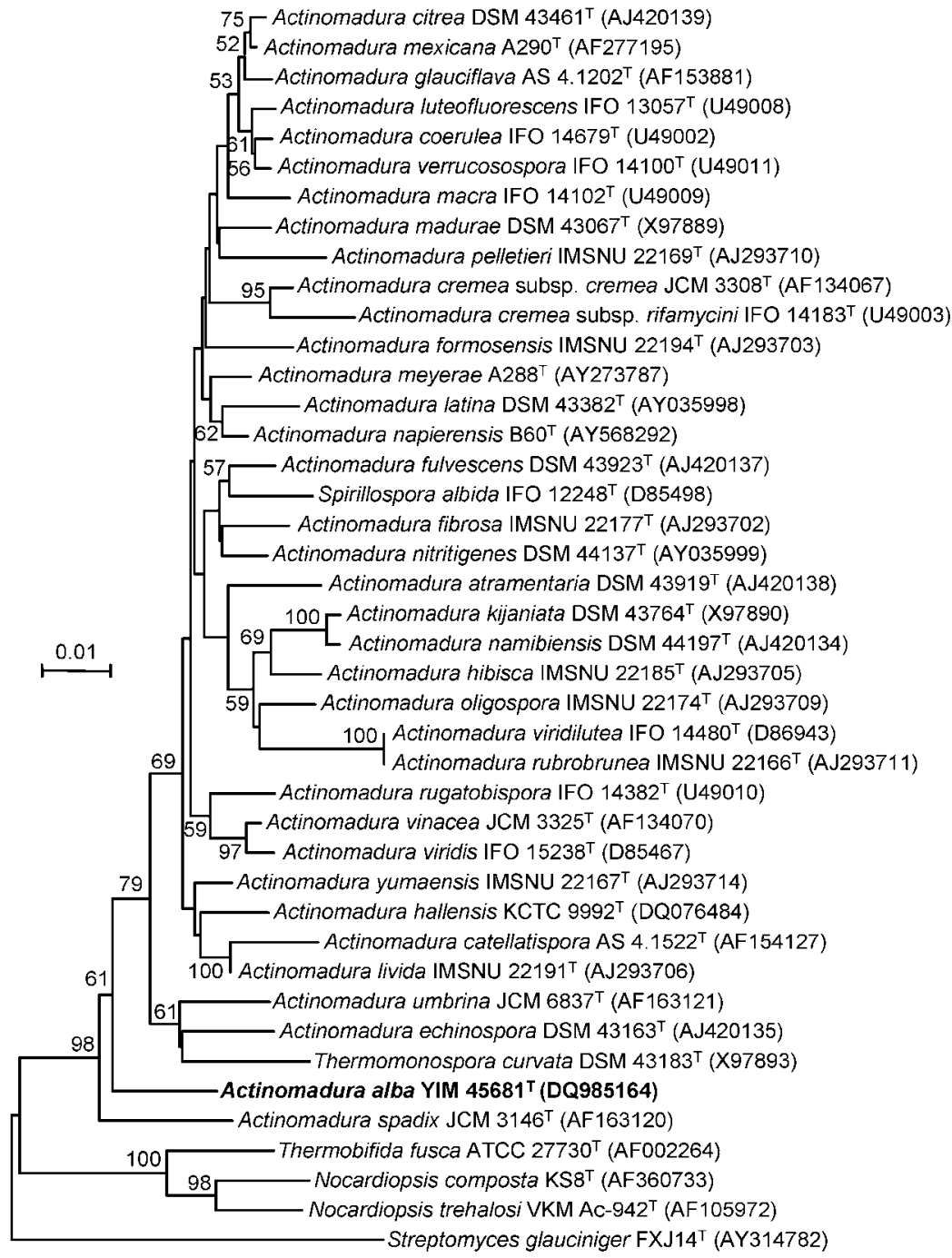

Fig. 2. Phylogenetic dendrogram obtained by distance matrix analysis of 16S rRNA gene sequences, showing the position of strain YIM $45681^{\top}$ and related phylogenetic neighbours. Numbers on branch nodes are bootstrap percentages (of 1000 resamplings); only values above $50 \%$ are shown. The sequence of Streptomyces glauciniger $\mathrm{FXJ14}{ }^{\top}$ was used as the outgroup. Bar, $1 \%$ sequence divergence. and phosphatidylinositol mannoside as the major polar lipids (phospholipid type I; Lechevalier et al., 1977), and the fatty acid profile is described in more detail in the species description.

Genomic DNA for PCR amplification was prepared from cells lysed by microwave: a small amount of biomass was transferred from solid medium to a new Eppendorf tube. After washing of the cells with $1 \mathrm{ml} \mathrm{PBS} \mathrm{(pH} \mathrm{8.0)} \mathrm{and} 1 \mathrm{ml}$ washing buffer (50 mM Tris/ $\mathrm{HCl}, \mathrm{pH} 7.7 ; 25 \mathrm{mM}$ EDTA; $0.1 \%$ SDS, $0.1 \%$ polyvinylpyrrolidone), $50 \mu$ lysis buffer (50 mM Tris/HCl, pH 8.0; 25 mM EDTA; $3 \%$ SDS; $1.2 \%$ polyvinylpyrrolidone) was added to resuspend the cells, which were then heated in a microwave oven at $700 \mathrm{~W}$ for $45 \mathrm{~s}$. Four hundred microlitres warm extraction buffer (10 mM Tris/HCl, pH 8.0; 1 mM EDTA; $0.5 \mathrm{M}$ sodium acetate; $1.2 \%$ polyvinylpyrrolidone, pre-warmed at $65{ }^{\circ} \mathrm{C}$ ) was then added immediately; after mixing, extraction was performed using the same volume of phenol/chloroform. The DNA was precipitated with isopropanol. After washing with $70 \%$ ethanol, the DNA was dissolved using $20 \mu \mathrm{lTE}$ solution.

PCR amplification and 16S rRNA gene sequencing were carried out as described previously (Cui et al., 2001). An almost-complete $16 \mathrm{~S}$ rRNA gene sequence for strain YIM $45681^{\mathrm{T}}$ was determined by direct sequencing of the PCRamplified gene. The $\mathrm{G}+\mathrm{C}$ content of the DNA, determined by using the HPLC method (Mesbah et al., 1989), was found to be $66.5 \mathrm{~mol} \%$.

A preliminary comparison between the almost-complete $16 \mathrm{~S}$ rRNA gene sequence of strain YIM $45681^{\mathrm{T}}$ (1479 bp) and sequences in the GenBank database indicated that the novel isolate was closely related to the members of the genus Actinomadura. A phylogenetic analysis was performed using the software packages PHYLIP (Felsenstein, 1993) and MEGA, version 2.1 (Kumar et al., 2001) after multiple alignment of the data using CLUSTAL_X (Thompson et al., 1997). Distances (using distance options according to 
the Kimura two-parameter model; Kimura, 1980, 1983) were calculated and clustering was performed with the neighbour-joining method (Saitou \& Nei, 1987). A bootstrap analysis (1000 resamplings) was used to evaluate the tree topology of the neighbour-joining data (Felsenstein, 1985). The phylogenetic analysis (Fig. 2) indicated that isolate $\mathrm{YIM} 45681^{\mathrm{T}}$ formed a distinct clade within the radiation encompassing members of the family Thermomonosporaceae, and that it was closely associated with members of the genus Actinomadura. The levels of $16 \mathrm{~S}$ rRNA gene sequence similarity between strain $45681^{\mathrm{T}}$ and its two closest neighbours, Actinomadura echinospora DSM $43163^{\mathrm{T}}$ and Actinomadura spadix JCM $3146^{\mathrm{T}}$, were 96.6 and $95.9 \%$, respectively (see Fig. 2).

It is clear from the phylogenetic analyses based on almostcomplete 16S rRNA gene sequences that our isolate belongs to the genus Actinomadura and represents a distinct genomic species (Stackebrandt \& Goebel, 1994). Support for the novel species status of the organism also comes from the phenotypic evidence shown in Table 1. Therefore, on the basis of the phenotypic and molecular genetic data, it is evident that strain YIM $45681^{\mathrm{T}}$ represents a novel species of the genus Actinomadura, for which we propose the name Actinomadura alba sp. nov.

\section{Description of Actinomadura alba sp. nov.}

Actinomadura alba (al'ba. L. fem. adj. alba white, referring to the white aerial mycelium).

Aerobic, Gram-positive. Cells grow well on ISP 2, ISP 3 and ISP 4 media and show moderate growth on ISP 5 and Czapek agar plates, forming a well-developed, nonfragmenting substrate mycelium. No diffusion pigment is produced on any of the media tested. On ISP 3 and ISP 4 media, a moderate amount of white aerial mycelium is formed; this matures into short spiral spore chains, and the spore surface is irregular. The optimal temperature and $\mathrm{pH}$ for growth are $28{ }^{\circ} \mathrm{C}$ and $\mathrm{pH}$ 7.0-8.0. Catalase- and ureasepositive. Nitrate is reduced to nitrite. $\mathrm{H}_{2} \mathrm{~S}$ is not produced. Gelatin liquefaction is observed. D-Mannitol, D-xylose, adonitol, D-ribose, D-fructose, D-trehalose, methyl $\alpha$-Dglucoside, maltose, D-lactose, sucrose and D-arabitol can be utilized as carbon sources, but glycerol, D-galactose, D-mannose, D-mannitol, L-rhamnose, D-cellobiose, myoinositol, D-arabinose, D-melibiose and D-raffinose are not utilized. Decomposes hypoxanthine, casein, aesculin, gelatin and starch. Does not decompose xanthine, DL-tyrosine or Tween 80. meso-Diaminopimelic is the diagnostic diamino acid, and the cell-wall sugars are ribose, xylose, madurose, galactose and glucose. The predominant menaquinones are MK-9 $\left(\mathrm{H}_{4}\right)$, MK- $9\left(\mathrm{H}_{6}\right)$ and MK-9 $\left(\mathrm{H}_{2}\right)$. The phospholipids are diphosphatidylglycerol, phosphatidylinositol, phosphatidylglycerol and phosphatidylinositol mannoside. The major fatty acids $(>10 \%)$ are iso- $\mathrm{C}_{16: 1} \mathrm{H}$ (19.77\%), $\mathrm{C}_{17: 1} \omega 8 c(18.51 \%), 10$-methyl $\mathrm{C}_{17: 0}(13.31 \%)$ and $\mathrm{C}_{16: 0}(11.03 \%)$. The $\mathrm{G}+\mathrm{C}$ content of the DNA of the type strain is $66.5 \mathrm{~mol} \%$.
The type strain, YIM $45681^{\mathrm{T}}\left(=\mathrm{DSM} 45045^{\mathrm{T}}=\mathrm{CCTCC}\right.$ AA206005 $5^{\mathrm{T}}$ ), was isolated from a soil sample collected in a suburb of Kunming, Yunnan Province, south-west China.

\section{Acknowledgements}

This research was supported by the National Basic Research Program of China (project no. 2004CB719601), the National Natural Science Foundation of China (project numbers 30560001 and 30600001) and the Yunnan Provincial Natural Science Foundation (project no. 2004 C0002Q). W.-J.L. was supported by the Program for New Century Excellent Talents in University.

\section{References}

Collins, M. D. \& Jones, D. (1980). Lipids in the classification and identification of coryneform bacteria containing peptidoglycans based on 2,4-diaminobutyric acid. J Appl Bacteriol 48, 459-470.

Collins, M. D., Pirouz, T., Goodfellow, M. \& Minnikin, D. E. (1977). Distribution of menaquinones in actinomycetes and corynebacteria. J Gen Microbiol 100, 221-230.

Cui, X. L., Mao, P. H., Zeng, M., Li, W. J., Zhang, L. P., Xu, L. H. \& Jiang, C. L. (2001). Streptomonospora salina gen. nov., sp. nov., a new member of the family Nocardiopsaceae. Int J Syst Evol Microbiol 51, 357-363.

Felsenstein, J. (1985). Confidence limits on phylogenies: an approach using the bootstrap. Evolution 39, 783-791.

Felsenstein, J. (1993). PHYLIP (phylogeny inference package), version 3.5c. Distributed by the author. Department of Genome Sciences, University of Washington, Seattle, USA.

Gordon, R. E., Barnett, D. A., Handerhan, J. E. \& Pang, C. H.-N. (1974). Nocardia coeliaca, Nocardia autotrophica, and the nocardin strain. Int J Syst Bacteriol 24, 54-63.

Holt, J. G., Krieg, N. R., Sneath, P. H. A., Staley, J. T. \& Williams, S. T. (editors) (1994). Bergey's Manual of Determinative Bacteriology, 9th edn. Baltimore: Williams \& Wilkins.

Kawato, M. \& Shinobu, R. (1959). On Streptomyces herbaricolor sp. nov., supplement: a simple technique for microscopical observation. Mem Osaka Univ Lib Arts Educ B Nat Sci 8, 114-119.

Kelly, K. L. (1964). Inter-Society Color Council - National Bureau of Standards Color-Name Charts Illustrated with Centroid Colors. Washington, DC: US Government Printing Office.

Kimura, M. (1980). A simple method for estimating evolutionary rates of base substitutions through comparative studies of nucleotide sequences. J Mol Evol 16, 111-120.

Kimura, M. (1983). The Neutral Theory of Molecular Evolution. Cambridge: Cambridge University Press.

Kroppenstedt, R. M., Stackebrandt, E. \& Goodfellow, M. (1990). Taxonomic revision of the actinomycete genera Actinomadura and Microtetraspora. Syst Appl Microbiol 13, 148-160.

Kumar, S., Tamura, K., Jakobsen, I.-B. \& Nei, M. (2001). MEGA2: molecular evolutionary genetics analysis software. Bioinformatics 17, 1244-1245.

Lechevalier, M. P. \& Lechevalier, H. A. (1970a). Composition of whole cell hydrolysates as a criterion in the classification of aerobic actinomycetes. In The Actinomycetales: The Jena International Symposium on Taxonomy, pp. 311-316. Edited by H. Prauser. Jena: Gustav Fischer.

Lechevalier, H. A. \& Lechevalier, M. P. (1970b). A critical evaluation of the genera of aerobic actinomycetes. In The Actinomycetales: The 
Jena International Symposium on Taxonomy, pp. 393-405. Edited by H. Prauser. Jena: Gustav Fischer.

Lechevalier, M. P., De Bièvre, C. \& Lechevalier, H. A. (1977). Chemotaxonomy of aerobic actinomycetes: phospholipid composition. Biochem Syst Ecol 5, 249-260.

MacFaddin, J. F. (1980). Biochemical Tests for Identification of Medical Bacteria, 2nd edn. Baltimore: Williams \& Wilkins.

Mesbah, M., Premachandran, U. \& Whitman, W. B. (1989). Precise measurement of the $\mathrm{G}+\mathrm{C}$ content of deoxyribonucleic acid by high-performance liquid chromatography. Int J Syst Bacteriol 39, 159-167.

Minnikin, D. E., Collins, M. D. \& Goodfellow, M. (1979). Fatty acid and polar lipid composition in the classification of Cellulomonas, Oerskovia and related taxa. J Appl Bacteriol 47, 17-22.

Miyadoh, S. \& Miyara, T. (2001). Family Thermomonosporaceae. In Identification Manual of Actinomycetes, pp. 281-291. Edited by the Society for Actinomycetes, Japan. Tokyo: Business Center for Academic Societies.

Pridham, T. G. \& Lyons, A. J. (1980). Methodologies for Actinomycetales with special reference to Streptomycetes and Streptoverticillia. In Actinomycete Taxonomy (Special publication no. 6), pp. 153 224. Edited by A. Dietz \& D. W. Thayer. Arlington, VA: Society for Industrial Microbiology.

Saitou, N. \& Nei, M. (1987). The neighbor-joining method: a new method for reconstructing phylogenetic trees. Mol Biol Evol 4, 406-425.
Shirling, E. B. \& Gottlieb, D. (1966). Methods for characterization of Streptomyces species. Int J Syst Bacteriol 16, 313-340.

Stackebrandt, E. \& Goebel, B. M. (1994). Taxonomic note: a place for DNA-DNA reassociation and $16 \mathrm{~S}$ rRNA sequence analysis in the present species definition in bacteriology. Int $J$ Syst Bacteriol 44, 846-849.

Staneck, J. L. \& Roberts, G. D. (1974). Simplified approach to identification of aerobic actinomycetes by thin-layer chromatography. Appl Microbiol 28, 226-231.

Suzuki, S. I., Okuda, T. \& Komatsubara, S. (1999). Selective isolation and distribution of Sporichthya strains in soil. Appl Environ Microbiol 65, 1930-1935.

Tamaoka, J., Katayama-Fujimura, Y. \& Kuraishi, H. (1983). Analysis of bacterial menaquinone mixtures by high performance liquid chromatography. J Appl Bacteriol 54, 31-36.

Thompson, J. D., Gibson, T. J., Plewniak, F., Jeanmougin, F. \& Higgins, D. G. (1997). The CLUSTAL_X windows interface: flexible strategies for multiple sequence alignment aided by quality analysis tools. Nucleic Acids Res 25, 4876-4882.

Zhang, Z., Wang, Y. \& Ruan, J. (1998). Reclassification of Thermomonospora and Microtetraspora. Int J Syst Bacteriol 48, 411-422.

Zhang, Z., Kudo, T., Nakajima, Y. \& Wang, Y. (2001). Clarification of the relationship between the members of the family Thermomonosporaceae on the basis of $16 \mathrm{~S}$ rDNA, 16S-23S rRNA internal transcribed spacer and 23S rDNA sequences and chemotaxonomic analyses. Int J Syst Evol Microbiol 51, 373-383. 